Evidence-Based

Speech-Language

Pathology and Audiology

\section{Fonoaudiologia Baseada}

em Evidências

Andréa Alves Maia

Ana Cristina Côrtes Gama²

Arthur Melo e Kümmer ${ }^{3}$

Keywords

Voice disorders

Dysphonia

Voice

Behavioral

Child behavior

Child

\section{Descritores}

Distúrbios da voz

Disfonia

Voz

Comportamento

Comportamento infantil

Criança

Correspondence address:

Andréa Alves Maia

Av. Marechal Campos, 1468, Campus UFES, Maruípe, Vitória (ES), Brasil, CEP: 29.040-090.

E-mail: andreaalvesmaia@yahoo.com.br

Received: $10 / 22 / 2012$

Accepted: 02/10/2014

\section{Behavioral characteristics of dysphonic children: integrative literature review}

\section{Características comportamentais de crianças disfônicas: revisão integrativa da literatura}

\begin{abstract}
Purpose: Integrative review of the scientific literature about the behavioral characteristics of dysphonic children discussing profiled and their etiologic relationship with the voice disorder, seeking to define recommendations on the importance of analyzing the behavior of children in voice assessment. Research strategy: Integrative review of articles published in the last 12 years, the Virtual Health Library. Selection criteria: Set up the theme of "behavioral characteristics of dysphonic children" was selected the databases LILACS, IBECS, MEDLINE, Cochrane Library, SciELO and ISI Web of Science and the following inclusion criteria: original articles, publication year from 2000 and 2012, Portuguese, English and Spanish. Data analysis: Among the 528 articles published childish voice and dysphonia, seven covered the topic researched and were included in the results. Results: Observed that four papers studied the behavior of children with vocal nodules, one addressed the behavioral characteristics of children with various types of dysphonic vocal fold lesion and three correlated Attention Deficit Disorder / Hyperactivity and dysphonia. Conclusion: Not established a behavioral profile of children with vocal disorders, but the results were consistent recommendation for the importance of this analysis in the evaluation of dysphonia in children.
\end{abstract}

\section{RESUMO}

Objetivo: Revisar de forma integrativa a literatura científica a respeito das características comportamentais de crianças disfônicas, discutindo o perfil traçado e sua relação etiológica com o distúrbio vocal, procurando definir recomendações sobre a importância da análise do comportamento infantil na avaliação vocal. Estratégia de pesquisa: Revisão integrativa de artigos publicados nos últimos 12 anos na Biblioteca Virtual em Saúde. Critérios de seleção: Definiram-se o tema "características comportamentais de crianças disfônicas", selecionaram-se as bases de dados LILACS, IBECS, MEDLINE, Biblioteca Cochrane, SciELO e Web of Science ISI, e os seguintes critérios de inclusão: artigos originais, ano de publicação entre 2000 e 2012 e idiomas português, inglês e espanhol. Análise dos dados: Entre os 528 artigos sobre voz e disfonia infantil publicados, sete abrangeram o tema pesquisado e foram incluídos nos resultados. Resultados: Observou-se que quatro artigos estudaram o comportamento de crianças com nódulos vocais, um abordou as características comportamentais de crianças disfônicas com vários tipos de lesão de prega vocal e três correlacionaram o Transtorno do Déficit de Atenção/Hiperatividade à disfonia. Conclusão: Não se estabeleceu um perfil comportamental de crianças com distúrbio vocal, mas os resultados foram consistentes na recomendação sobre a importância desta análise na avaliação da disfonia em crianças.

Study carried out at the Graduate Program in Health Sciences at Universidade Federal de Minas Gerais UFMG - Belo Horizonte (MG), Brazil.

(1) Graduate Program in Health Sciences, School of Medicine, Universidade Federal de Minas Gerais - UFMG Belo Horizonte (MG), Brazil.

(2) Speech-Language Pathology and Audiology Course, Universidade Federal de Minas Gerais - UFMG Belo Horizonte (MG), Brazil.

(3) Department of Mental Health, School of Medicine, Universidade Federal de Minas Gerais - UFMG Belo Horizonte (MG), Brazil.

Conflict of interests: nothing to declare. 


\section{INTRODUCTION}

According to epidemiological studies, dysphonia is a common symptom in childhood, with a prevalence of $6-38 \%^{(1-5)}$, and it can adversely impact a child's life in the aspects of overall health, communicative efficiency, social and educational development and participation in group activities in school ${ }^{(6)}$. The vocal disorder promotes a negative effect on how the child is perceived by adults and by their peers ${ }^{(6)}$ and is more prevalent in males ${ }^{(1)}$.

In childhood, there are no significant anatomical and physiological differences between male and female larynges. Therefore, the higher prevalence of dysphonia and vocal nodules in children can be explained by personality traits ${ }^{(1,7-10)}$ and inappropriate vocal behaviors ${ }^{(8)}$. Other differences studied as likely explanations are the physical and social activities for boys that require excessive vocal use ${ }^{(1,7,9,10)}$, but there is still no consensus, and studies are needed to confirm or refute these differences in personality and behavior between genders in childhood that may justify their association with childhood dysphonia ${ }^{(11)}$.

Childhood dysphonia has a diverse and multicausal etiology, and may be organic, behavioral or related to emotional factors ${ }^{(12)}$. Among these causes, the most common one is functional, related to voice abuse and misuse behaviors, with vocal nodules being the most frequent laryngeal lesion ${ }^{(2,7,8,13,14)}$. Studies have shown that these deviant vocal behaviors can be interpreted as a form of interaction, aggression, leadership or desire to become accepted by a group, resulting from the combination of anatomical, physiological, social, emotional or environmental factors ${ }^{(15,16)}$ and are present in $39.6 \%$ of children aged five to seven years old, in the perception of parents ${ }^{(17)}$. Such behaviors may be the first symptom of neuropsychiatric disorders, which lead to the aforementioned emotional, social, and behavioral problems ${ }^{(18)}$.

Thus, studies seek to understand childhood vocal disorder and define recommendations for preventive and therapeutic interventions with risk factors. Studies ${ }^{(19-21)}$ have suggested that there is an association between voice disorders, personality, and behavior, for both adults and children.

\section{OBJECTIVE}

The objective of this article was to realize a integrative review and critically analyze the literature regarding the behavioral characteristics of dysphonic children, discuss the profile outlined and its relation to the etiology of voice disorders, while trying to point out recommendations on the importance of child behavior analysis in voice assessment.

\section{METHODS}

\section{Research strategy and selection criteria}

To achieve that goal, an integrative review of literature ${ }^{(22)}$ was used in order to get a better understanding on the subject based on previous studies. Under this method ${ }^{(22)}$, the review gathers and systematizes research findings on a defined topic or issue in a systematic and orderly manner, seeking to contribute to the deepening of knowledge.

Thus, the analysis of literature followed six stages ${ }^{(22)}$. In the first stage, we defined the theme "behavioral characteristics of dysphonic children", and in the second, the following databases were selected for the literature search: LILACS, IBECS, MEDLINE, The Cochrane Library, SciELO (brasil.bvs.br) e Web of Science ISI (http://periodicos.capes.gov.br). The following inclusion criteria were considered: original articles, publication year between 2000 and 2012, and articles written in Portuguese, English, and Spanish.

For the literature search, the following terms were used: voice disorders, childhood dysphonia, voice disturbance, dysphonia, voice and vocal fold, always containing the limit "child", and 528 articles that studied voice and voice disorders in childhood were found.

A tentative to refine the search was made, using descriptors related to behavior: behavior, psychological, child behavior, child behavior disorders, social behavior, but this strategy excluded articles that address specific behavioral characteristics, such as temperament and hyperactivity, among others used in the studies. The study selection strategy defined in the third stage of the review was reading the abstracts of the 528 articles in BVS and ISI.

Through the abstracts, seven articles that approached Through the abstracts, seven articles covering the topic "behavioral characteristics of dysphonic children" were chosen, which are as follows: Hamdan et al. ${ }^{(18)}$; Niedzielski et al. ${ }^{(23)}$; Maia et al. ${ }^{(24)}$; Vicari et al. ${ }^{(25)}$; Roy et al. ${ }^{(26)}$; Angelillo et al. ${ }^{(27)}$; and Edgger et al. ${ }^{(28)}$.

In the fourth stage of categorizing the eight selected studies, it was observed that four of them studied the behavior of children with vocal nodules ${ }^{(23,24,26,28)}$, one assessed the behavioral characteristics of dysphonic children with various types of vocal fold lesions ${ }^{(27)}$ and three correlated Attention Deficit Hyperactivity Disorder and dysphonia ${ }^{(18,24,25)}$ (Chart 1).

The fifth stage involved the bibliometric analysis for characterization of the selected studies. Subsequently, the concepts discussed in each article and the researchers' interests were extracted. The studies were compared and grouped by the similarity of content, with two categories for analysis being built, as follows: general behavioral characteristics of children with dysphonia, and Attention Deficit Hyperactivity and dysphonia.

From there, articles were discussed, enabling the synthesis of knowledge and completing the sixth stage of the integrative review of the subject.

\section{RESULTS}

\section{General behavioral characteristics of dysphonic children}

Edgger et al. ${ }^{(28)}$ compared the temperamental characteristics of three groups of children, distinguished by the type of communication disorder. One group comprised 69 stuttering children, the second 146 children with developmental disorder and the third 41 children with vocal nodules. They used the Children's Behavior Questionnaire (CBQ), which analyzes the temperament, i.e., assesses individual differences in domains in 
the child's levels of action, attention, and affection, related to emotional reactivity, excitation, and self-regulation, constructs considered central in temperament. This instrument consists of 15 scales that are grouped into three dimensions, namely negative affectivity, extraversion, and control by effort ${ }^{(28)}$.

In this study ${ }^{(28)}$, the structural factor temperament was strongly similar among the three groups. In the analysis by scales, children with vocal nodules showed strong irritation/ frustration factor (focuses on negative affectivity related to interruption of ongoing tasks); sadness (consists of negative affectivity, low mood, and energy related to exposure to suffering, disappointment, and loss); sensitivity/response threshold (focuses on the detection of low intensity, light stimuli from the external environment); fear (focuses on the negative affectivity, including unease, worry or nervousness, which is related to anticipation of pain or stress and/or potentially threatening situations); discomfort (consists of negative affectivity related to sensory qualities of stimulation), all corresponding to the negative affectivity dimension in behavioral conduct ${ }^{(28)}$.

Roy et al. ${ }^{(26)}$ studied the behavioral characteristics of 26 children with vocal nodules using the Child Behavior Checklist (CBCL), validated for Brazil with the name Inventário do Comportamento da Criança para Pais (ICCP) ${ }^{(29)}$ which aims to describe and evaluate social skills and behavior problems of children/adolescents, as they are perceived by their parents or their substitutes. CBCL has two parts, the first consisting of 20 questions on the quantity and quality of the subject's involvement in various social interaction activities and situations, from sports and hobbies to the number of friends and involvement in clubs and teams, for instance; the second part consists of 120 items related to various behavioral and/or emotional disturbances ${ }^{(26)}$.

The results of this study ${ }^{(26)}$ showed that children with and without vocal nodules had CBCL total scores within the normal range and were differentiated by the social scale, suggesting that children with vocal nodules have more friends, spend more time with them and engage in more organizations. Thus, the authors concluded that social behavioral characteristics of these children are consistent with vocal use. In the analysis by item, the behaviors "crying a lot" and "nagging a lot" also had a significant association with the presence of vocal nodules ${ }^{(26)}$.

The third study, from Niedzielski et al. ${ }^{(23)}$, described the behavior of children after discharge from speech-language therapy for dysphonia due to vocal nodules, assessing the psychological profile of 14 children by clinical analysis and concluding that these boys are more excitable, nervous, independent, and often individualistic, with a tendency to lead and dominate. These authors concluded that psychotherapy can complement the traditional treatment for vocal nodules in children $^{(23)}$.

In another study, from Angelillo et al. ${ }^{(27)}$, the behavioral trait of hyperactivity was related to childhood voice disorder

Chart 1. List of studies on the behavior of children with voice disorders

\begin{tabular}{|c|c|c|c|c|c|}
\hline Study & Location & $\begin{array}{c}\text { Laryngeal or } \\
\text { vocal diagnostic }\end{array}$ & $\mathrm{n}$ & $\begin{array}{c}\text { Behavioral assessment } \\
\text { instrument }\end{array}$ & Behavioral characteristics of dysphonic children \\
\hline Niedzielski et al. ${ }^{(23)}$ & $\begin{array}{l}\text { Republic of } \\
\text { Poland }\end{array}$ & $\begin{array}{l}\text { Post-treatment } \\
\text { of vocal nodules }\end{array}$ & $\begin{array}{l}\text { Study Group: } 112 \\
\text { Control Group: } 31\end{array}$ & $\begin{array}{l}\text { Clinical psychological } \\
\text { evaluation }\end{array}$ & $\begin{array}{l}\text { - More excitable, nervous, independent and often } \\
\text { individualistic. } \\
\text { - Increased tendency for leadership and } \\
\text { dominance. }\end{array}$ \\
\hline Maia et al. ${ }^{(24)}$ & Brazil & $\begin{array}{l}\text { Vocal nodules } \\
\text { and dysphonia }\end{array}$ & $\begin{array}{l}\text { Study Group: } 10 \\
\text { Control Group: } 10\end{array}$ & SNAP-IV & $\begin{array}{l}\text { - Traits indicating Attention Deficit Hyperactivity } \\
\text { Disorder } \\
\text { - Traits of hyperactivity/impulsivity and inattention }\end{array}$ \\
\hline Vicari et al. ${ }^{(25)}$ & Brazil & Dysphonia & $\begin{array}{l}\text { Study Group: } 40 \\
\text { Control Group: } 31\end{array}$ & $\begin{array}{l}\text { Criteria on the Diagnostic } \\
\text { and Statistical Manual } \\
\text { of Mental Disorders - IV } \\
\text { Edition (DSM-IV) }\end{array}$ & $\begin{array}{l}\text { - There is no statistically significant relationship } \\
\text { between vocal disorders and Attention Deficit } \\
\text { Hyperactivity Disorder }\end{array}$ \\
\hline Hamdan et al..$^{(17)}$ & Lebanon & Dysphonia & $\begin{array}{l}\text { Study Group: } 19 \\
\text { Control Group: } 19\end{array}$ & $\begin{array}{l}\text { Criteria on the Diagnostic } \\
\text { and Statistical Manual } \\
\text { of Mental Disorders - IV } \\
\text { Edition (DSM-IV) }\end{array}$ & $\begin{array}{l}\text { - Attention Deficit Hyperactivity Disorder of the } \\
\text { Combined subtype }\end{array}$ \\
\hline Angelillo et al..$^{(27)}$ & Italy & $\begin{array}{l}\text { Dysphonia and } \\
\text { various types of } \\
\text { vocal fold lesion }\end{array}$ & 312 & $\begin{array}{l}\text { Clinical Neuropsychiatric } \\
\text { Evaluation }\end{array}$ & $\begin{array}{l}\text { - } 83 \% \text { with attitudes of hyperactivity and } \\
\text { aggression }\end{array}$ \\
\hline Egger et al. ${ }^{(28)}$ & $\begin{array}{l}\text { Kingdom of } \\
\text { Belgium }\end{array}$ & Vocal nodules & $\begin{array}{l}\text { Group 1: } 69 \\
\text { Group 2: } 146 \\
\text { Group 3: } 41\end{array}$ & $\begin{array}{l}\text { Chidren's Behavior } \\
\text { Questionnaire (CBQ) }\end{array}$ & $\begin{array}{l}\text { - Strong negative affectivity factor contained } \\
\text { in the scales: irritation/frustration; sadness; } \\
\text { sensitivity; discomfort }\end{array}$ \\
\hline
\end{tabular}


in an epidemiological study with 312 dysphonic children, $92 \%$ being of functional etiology. In this study ${ }^{(27)}$ an $83 \%$ prevalence of hyperactivity and aggression attitudes was observed in dysphonic children in school and family environments, through clinical neuropsychiatric evaluation.

\section{Attention deficit hyperactivity disorder and dysphonia}

The behaviors of hyperactivity/impulsivity and attention deficit were evaluated in children with and without vocal nodules by the SNAP-V scale in the article from Maia et al. ${ }^{(24)}$. This scale is constructed by 18 items referring to behavior related to ADHD symptoms, described by the Diagnostic and Statistical Manual of Mental Disorders - IV Edition (DSM-IV) of the American Psychiatric Association. They compared the behaviors of 10 children with vocal nodules and 10 without vocal nodules, matched for age and gender. The authors concluded that these groups differ in scores that indicate the presence of a trace of inattention, hyperactivity/impulsivity, and in the total score indicative of the presence of $\mathrm{ADHD}^{(24)}$.

Inconsistently with the previous study, other researchers $^{(25)}$, studying only males compared two groups of children aged between 8 and 11 years, distinguished by the presence of signs and symptoms of ADHD, and concluded that there is no relationship between vocal disorders and ADHD. However, the presence of the psychiatric disorder correlates to a greater degree of vocal disorder ${ }^{(25)}$.

Another study, from Hamdan et al. ${ }^{(18)}$, also associated dysphonia and ADHD, but only children with ADHD of the combined subtype were selected for the experimental group. It was concluded that it is a risk factor for childhood dysphonia. In this study, the authors found that children with Combined ADHD have more strong and tense voices, noisy and breathy when compared to children without $\mathrm{ADHD}^{(18)}$. The authors reported that the study has limitations for its sample size and by the absence of laryngeal evaluation of children, which could explain the greater vocal misuse in this population by the presence of edema or nodules in the vocal folds ${ }^{(18)}$.

\section{RESULTS}

The voice is one of the expressions that reveals elements of biological, psychological, social, and educational dimensions ${ }^{(30)}$. Thus, it is logical to think that certain behavioral characteristics may be associated with the onset of dysphonia. However, it is observed that there is little research in this area for the pediatric population and that there is no consensus on this association in the studies.

In studies carried out with instruments that assessed the overall behavior pattern, $\mathrm{CBQ}^{(28)}$ and $\mathrm{CBCL}^{(26)}$, it was observed that dysphonic children do not differ from children without dysphonia, or children with other communication disorders. However, in the analysis of specific behavioral traits, those with voice disorders are characterized by having different social activities $^{(26)}$; for the hyperactivity/impulsivity ${ }^{(18,24,27)}$ and negative affectivity in the definition of actions ${ }^{(28)}$.
One hypothesis to be tested is whether the tendency of the individual to the social area, with emphasis on verbal communication (speech), can have consequences for the vocal behavior in the form of phonotrauma, as found in one of the research's correlation between increased voice volume and greater sociability and extroversion ${ }^{(31)}$.

Studies ${ }^{(26,28)}$ suggest that there is no typical behavioral profile in children with vocal nodules, as stated in earlier studies that characterize them as aggressive, distracted, immature, and as having disorders related to the pair ${ }^{(20,21,32-34)}$.

All studies related to the association between ADHD and childhood dysphonia followed the same method of diagnosis of the disorder, the DSM-IV, but with different sample selection criteria, which reduces the strength of the evidence found in the comparison between them. Studying only boys indicating the presence of ADHD, researchers ${ }^{(25)}$ did not find the positive association found by other authors ${ }^{(24)}$. In the sample of children presenting only the combined subtype of ADHD, the association of these disorders was positive ${ }^{(18)}$.

The childhood dysphonia may be associated with perceptual and psychosocial problems ${ }^{(13)}$. By analyzing the articles, this voice disorder is associated with psycho-behavioral characteristics, and the functional characterization of these behaviors can assist in therapeutic management and guide future research.

None of the studies analyzed addressed the difference in behavior between genders in order to discuss the factor as the explanation for the higher incidence of dysphonia in children, as suggested by other researchers ${ }^{(1,7-10)}$.

The search results show the small amount of studies linking global behavior to vocal characteristics in childhood. Moreover, most of them did not use validated and reliable instruments.

No studies on behavioral assessment methods based on direct observation, behavioral experiments, and psychophysiological measures were found, which would allow more thorough and objective assessment of the various dimensions that surround children's behavior, which may or may not be associated with the habits of vocal abuse and misuse, and thus to dysphonia.

Hoarseness should not be identified as part of the normal development of children; the plays and habits, in turn, need to be reviewed for the proper maintenance of voice and the full development of communication, social and emotional adjustment, and the child's speech ${ }^{(17)}$. Possible causes and maintaining factors that may be related to voice disorders in children are clarified by more detailed characterization of their behavior. Moreover, multidisciplinarity is essential in the diagnosis and treatment of voice disorders.

\section{CONCLUSION}

The integrative review of the behavioral characteristics of dysphonic children does not establish a profile, and the relation of cause and effect has not been confirmed. However, the results are consistent in the recommendation about the importance of analysis in the assessment of this symptom. 
*AAM was responsible for the project, study design, data collection and tabulation of data; AMK supervised the collection and collaborated with the data analysis; ACCG was responsible for the overall direction of the stages of implementation and preparation of the manuscript.

\section{REFERENCES}

1. Carding PN, Roulstone S, Northstone, K. The ALSPAC Study Team. The prevalence of childhood dysphonia: a cross-sectional study. J Voice. 2006;20(4):623-30.

2. Melo ECM, Mattioli FM, Brasil OCO, Behlau M, Pitaluga ACA, Melo DM. Disfonia infantil: aspectos epidemiológicos. Rev Bras Otorrinolaringol. 2001;67(6):804-7.

3. Hirschberg J, Dejonckere PH, Hirano M, Mori K, Schultz-Coulon HJ, Vrticka K. Voice disorders in children. Int J Pediatr Otorhinolaryngol. 1995;32(suppl.):S109-25.

4. Simões M, Rosa AHO, Soares JC, Ribeiro LR, Imamura VM, Bitar ML. Alteração vocal em crianças que frequentam creche. Pró-Fono. 2002;14(3):343-50.

5. Oliveira RC, Teixeira LC, Gama ACC, Medeiros AM. Análise perceptivo-auditiva, acústica e autopercepção vocal em crianças. J Soc Bras Fonoaudiol. 2011;23(2):158-63.

6. Connor NP, Cohen SB, Theis SM, Thibeault SL, Heatley DG, Bless DM. Attitudes of children with dysphonia. J Voice. 2008;22(2):197-209.

7. Silverman EM. Incidence of chronic hoarseness among school-age children. J Speech Hear Dis. 1975;40(2):211-5.

8. Hunt J, Slater A. Child dysphonia - harmony and balance. Human Comminic. 1996;5(4):21-3.

9. Martins RHG, Trindade SHK. A criança disfônica: diagnóstico, tratamento e evolução clínica. Rev Bras Otorrinolaringol. 2003;69(6):801-6.

10. Akif Kiliç M, Okur E, Yildirim I, Güzelsoy S. The prevalence of vocal fold nodules in school age children. Int J Pediatr Otorhinolaryngol. 2004;68(4):409-12.

11. Maia AA, Duarte MA, Gama ACC, Silveira JCC. Avaliação da voz e do comportamento vocal em crianças com transtorno do déficit de atenção/ hiperatividade. In: Anais do $17^{\circ}$ Congresso Brasileiro de Fonoaudiologia e $1^{\circ}$ Congresso Ibero-Americano de Fonoaudiologia; 2009 Out 21-24; Salvador.

12. Dejonckere PH. Voice problems in children: pathogenesis and diagnosis Int J Pedriatr Otorhinolaryngol. 1999;49(suppl):S311-4.

13. Freitas MR, Weckx LLM, Pontes PA. Disfonia na infância. Rev Bras Otorrinolaringol. 2000;66(3):257-64.

14. McMurray JS. Disorders of phonation in children. Pediatr Clin North Am. 2003;50(2):363-80.

15. Hersan RC. Avaliação de voz em crianças. Pró-Fono. 1991;3(1):3-9.

16. Andrews ML. Terapia vocal para crianças: os primeiros anos escolares. Porto Alegre: Artes Médicas; 1998.
17. Takeshita TK, Aguiar-Ricz L, Isaac ML, Ricz H, Anselmo-Lima W. Comportamento vocal de crianças em idade pré-escolar. Arq Int Otorrinolaringol. 2009;13(3):252-8.

18. Hamdan AL, Deeb R, Sibai A, Rameh C, Rifai H, Fayyad J. Vocal characteristics in children with attention deficit hyperactivity disorder. J Voice. 2009;23(2): 190-4.

19. Roy N, Bless DM, Heisey D. Personality and voice disorders: a multi trait-multi disorder analysis. J Voice. 2000;14(4):521-48.

20. Wilson FB, Lamb MM. Comparison of personality characteristics of children with and without vocal nodules based on Rorschach protocol interpretation. Acta Symbol. 1974;5(1):43-55.

21. Green G. Psycho-behavioral characteristics of children with nodules: WPBIC ratings. J Speech Hear Disord. 1989;54:306-12.

22. Mendes KDS, Silveira RCCP, Galvão CM. Revisão integrativa: método de pesquisa para a incorporação de evidências na saúde e na enfermagem. Texto Contexto - enferm. 2008;17(4):758-64.

23. Niedzielski A, Niedzielska G, Gwizda G. Personality features of children treated due to vocal nodules. Ann Univ Mariae Curie Sklodowska Med. 2002;57(2):53-7.

24. Maia AA, Gama AC, Michalick-Triginelli MF. Relação entre transtorno do déficit de atenção/hiperatividade, dinâmica familiar, disfonia e nódulo vocal em crianças. Rev Ciênc Med. 2006;15(5):379-89.

25. Vicari MI, Behlau M, Schwartzman JS. Desvios vocais e presença de sinais e sintomas do transtorno de déficit de atenção/hiperatividade TDAH. Temas Desenvolv. 2007;15(87/88):34-38.

26. Roy N, Holt KI, Redmond S, Muntz H. Behavioral characteristics of children with vocal fold nodules. J Voice. 2007;21(2):157-68.

27. Angelillo N, Di Costanzo B, Angelillo M, Costa G, Barillari MR, Barillari U. Epidemiological study on vocal disorders in pediatric age. J Prev Med Hyg. 2008;49:1-5.

28. Eggers K, De Nil LF, Van den Bergh BR. Factorial temperament structure in stuttering, voice-disordered, and typically developing children. J Speech Lang Hear Res. 2009;52(6):1610-22.

29. Fonseca AC, Simões A, Rebelo JA, Ferreira JAG, Cardoso F. Um inventário de competências sociais e de problemas de comportamento em crianças e adolescentes: o Child Behavior Checklist de Achenbach. Psychologica. 1994;12:55-78.

30. Morrison M, Rammage L, Nichol H, Pullan B, May P, Salked L. Psychological management of the voice disordered patient. In: eds. The management of voice disorders. $4^{\mathrm{a}}$ ed. San Diego: Singular Publishing Group; 1994. p.98-109.

31. Von Fritsch A, Oliveira G, Behlau M. Opinião dos pais sobre a voz, características de comportamento e de personalidade de seus filhos. Rev CEFAC. 2011;13(1):112-22.

32. Wilson FB. Emotional stress may cause voice anomalies in kids. JAMA. 1971;216:2085.

33. Dejonckere PH. Pathogenesis of voice disorders in childhood. Acta Otorhinolaryngol Belg. 1984;38(3):307-14.

34. Von Leden H. Vocal nodules in children. Ear Nose Throat J. 1985;64:473-80. 